\title{
Entrepreneurial practices in research-intensive and teaching-led universities
}

\author{
Maria Abreu • Pelin Demirel • \\ Vadim Grinevich • Mine Karataş-Özkan
}

Accepted: 7 June 2016/Published online: 29 June 2016

(C) The Author(s) 2016. This article is published with open access at Springerlink.com

\begin{abstract}
In recent years, there has been increased pressure on universities to deliver on their third mission. In the UK context, universities are encouraged to explicitly assume responsibility for facilitating economic growth, with a particular emphasis being given to the role played by the research-led institutions. Using a broad definition of entrepreneurial practices in universities, the aim of this paper was to extend the analysis of entrepreneurial activities to teaching-led universities besides their research-intensive counterparts. Results, based on micro-data on over 22,000 academics in the sciences, social sciences, arts and humanities across all higher education institutions in the UK, indicate that the levels and geographical reach of the diverse set of entrepreneurial practices conducted by research-intensive and teaching-led universities differ significantly. The underlying reasons for these differences are explored
\end{abstract}

Electronic supplementary material The online version of this article (doi:10.1007/s11187-016-9754-5) contains supplementary material, which is available to authorized users.

\section{Abreu}

Department of Land Economy, University of Cambridge, 19 Silver Street, Cambridge CB3 9EP, UK

P. Demirel · V. Grinevich $(\bowtie) \cdot$ M. Karataş-Özkan Southampton Business School, University of Southampton, Highfield, Southampton SO17 1BJ, UK e-mail: v.grinevich@soton.ac.uk through the lens of institutional theory and by utilising the Blinder-Oaxaca decomposition technique.

Keywords Entrepreneurial university · Third mission · Institutional theory $\cdot$ Regional entrepreneurship

JEL classifications $\quad \mathrm{O} 32 \cdot \mathrm{O} 33 \cdot \mathrm{L} 26 \cdot \mathrm{R} 10$

\section{Introduction}

In recent years, there has been an increasing pressure on universities to deliver on their third mission in addition to their core functions, namely research and education. Third mission involves knowledge exchange in its broader sense, including commercialisation of research, university-industry partnerships, and all related enterprise engagements. In the UK context, universities are encouraged to explicitly assume responsibility for facilitating economic growth, with a particular emphasis being given to the role played by the research-led institutions (Perkmann et al. 2013; Witty Review 2013). It is also suggested that the mode of university-industry collaborations should primarily be defined by technology and industry opportunity rather than location and regional context. University engagement on a local level is encouraged too, but is contingent on whether this would help to mobilise national clusters to 
promote high-growth firms in new research-led sectors (ibid).

The current UK policy focus on research-led universities and their role in promoting international competitiveness is consistent with the view of the university as a provider of technological knowledge, critical for innovation and economic growth (Mian 2011; Markman et al. 2005). Related to this is the academic discourse on the economic and geographical dimensions of university-industry links, which tends to focus on tangible, easy to quantify, knowledge transfer mechanisms such as patenting, licensing and knowledge-intensive spinouts (Agrawal and Henderson 2002; Di Gregorio and Shane 2003; Thompson and Fox-Kean 2005). These are normally associated with the commercialisation activities of researchintensive universities, with few knowledge transfer effects being reported in the context of less researchintensive institutions (Bonaccorsi et al. 2014).

Nevertheless, there is a small but growing literature indicating that the less research-intensive universities (henceforth referred to as "teaching-led", which indicates those universities with a primary focus on education and student experience rather than research) may play an important role in promoting technology clusters (Calzonetti et al. 2012; Braunerhjelm and Helgesson 2006). This is mainly due to their proactive leadership in regional capacity building and networking, rather than on "pushing" innovations via the formal knowledge-commercialisation routes. This "bricoleur" or technology cluster facilitator role can be conceptualised as one of the entrepreneurial functions of the university (Audretsch 2014). This role is normally associated with broader, less formal, activities and commitments that contribute to the entrepreneurial environment (Klofsten and JonesEvans 2000), but remain largely overlooked by the literature. A closer look into strategies and engagements of teaching-led universities is imperative given the recent policy changes in the UK higher education system (see Higher Education Green Paper 2015). UK government is determined to open up higher education to new providers that will come in various shapes and sizes; their common denominator will be focus on teaching rather than research (Black et al. 2015).

The aim of this paper is to place a focus on the entrepreneurial activities of both research-intensive and teaching-led universities. More specifically, we analyse the role of these two types of the university as a contributor to both innovation and entrepreneurship (Urbano and Guerrero 2013). Departing from the view that research-intensive universities specialise in innovation-related knowledge exchange, with the teaching-led universities focusing on facilitating an entrepreneurship context only; we expect a more complex configuration, with both types of the university adopting these roles to a different extent along different geographical scales (local, regional, national and international). Understanding these multi-level differences and the internal and contextual factors behind them should lead to a more nuanced view of the entrepreneurial university, and its role in the development of entrepreneurial ecosystems (Acs et al. 2014).

When exploring the entrepreneurial university, we go beyond the conventional set of licensing and spinout activities. Following the insights of the prior literature (Clark 1998; Lester 2005; Gilman and Serbanica 2015 amongst others), we consider a broader range of entrepreneurial activities, referred as "problem-solving activities" including consultancy, contract research and joint research with external organisations; participation in research consortia, providing informal advice, prototyping and testing for external organisations, hosting personnel from external organisations and secondments. We argue for a view of the university as an institution made up of autonomous individuals (Howells et al. 2014). Based on the insights from institutional theory (Thornton et al. 2013; Scott 2014), we conceptualise the differences in the extent and scope of entrepreneurial activities as a function of differences in the characteristics and values of individual academics (cognitive level), their behavioural responses to normative expectations (normative level) and regulatory protocols within their disciplines and institutions (regulative level). Our analysis is based on a unique survey of UK academics conducted over 2008/2009. The survey provides micro-data on over 22,000 academics in the sciences, social sciences, arts and humanities, covering all higher education institutions in the UK. These data are complemented using institution-level information on financial and logistical support for entrepreneurial activities provided by the UK Higher Education Statistics Agency (HESA).

The study includes descriptive analysis on the extent and geography of different types of entrepreneurial engagements, and a decomposition analysis to show whether the differences between research- 
intensive and teaching-led universities are due to differences in the characteristics of the academics (endowment effects) or differences in the effects of these characteristics on the outcomes (coefficient effects). Our results indicate that the proportion of academics engaged in licensing and spin-out activities is higher in research-intensive universities, and the same is true for problem-solving activities overall, although there are some types of activities for which the engagement gap is much less pronounced. These include hosting of industry personnel and academic secondment to industry, consultancy services and prototyping or testing for external organisations, suggesting that teaching-led universities are more effective in engaging in less formal types of entrepreneurial activity. The results from the geographical analysis of the problem-solving activities suggest that there is a pattern of specialisation in terms of the geographical reach of entrepreneurial engagements with research-intensive universities taking a more active role at the national/international level and teaching-led universities dominating at the local/ regional level. The decomposition analysis indicates that the differences in patterns of entrepreneurial activities, particularly at the local level, between the research- and teaching-led universities are mainly due to the coefficients (or behavioural responses) rather than the endowments.

The remainder of the paper is organised as follows. Section 2 reviews the literature on the scope of the entrepreneurial university, and Sect. 3 presents our conceptual framework and hypotheses. Section 4 discusses the data sources and methods used in the analysis. Section 5 presents and discusses our empirical results, and Sect. 6 concludes.

\section{Scope of the entrepreneurial university}

It is widely acknowledged that the role of the university in the economy and society has evolved over time from being the Humboldtian "ivory tower", which is concerned with advancing of fundamental knowledge with limited connection with the outside world, to being one of the driving forces of innovation and entrepreneurship (Audretsch 2014). The increasing and pro-active engagement of the university with non-academic partners, networks and institutions is interpreted as a natural development of the university mission to address the demands of a modern knowledge-based economy and entrepreneurial society (Etzkowitz 2003; Audretsch 2014).

When considering entrepreneurial practices of the university, the literature tends to focus on commercialisation of university research via patenting, licensing and spin-outs, and the related institutional instruments such as technology transfer offices, incubators and science parks (Rothaermel et al. 2007; Shane 2004; Guerrero and Urbano 2014; Markman et al. 2005). The notion of the entrepreneurial university is often placed in the context of technology transfer only, implying that only certain parts of the university can contribute to its third stream mission (Audretsch 2014). Related to this is a perspective that the entrepreneurial activities of the university are likely to be greater in a knowledge-intensive context, i.e. where investment in new knowledge is relatively high (Guerrero and Urbano 2014).

This dominant view of the entrepreneurial university as an institution mainly concerned with the commercialisation of technological knowledge deviates from its original and wider conceptualisation by Clark (1998), who argued that the entrepreneurial university phenomenon is multidimensional and relates to the entire university at all its levels, which include research, teaching and governance. Clark (1998)'s view is now gaining further support in the context of the recent debate on the complexity of the university role in the emerging entrepreneurial society (Audretsch 2014; Urbano and Guerrero 2013). Rather than just generating technology transfer, the university is expected to provide leadership in entrepreneurial and creative thinking, and action across the education, research and engagement domains.

A multidimensional characterisation of the mission of the entrepreneurial university resonates well with Lester' s taxonomy of the university engagement with the economy and society (Lester 2005) as well as a growing literature that covers a broader range of entrepreneurial activities (see Gilman and Serbanica 2015 for a review). This definition goes beyond the conventional set of patent-based and spin-out activities to incorporate the "public space" function of the university, which may relate to a wide range of formal and informal interactions outside the university (Klofsten and Jones-Evans 2000; D'Este and Patel 2007), and may in turn drive teaching and research activities. Different types of universities (such as comprehensive 
universities, specialised research and teaching institutions) tend to differentiate themselves in relation to different types of engagement, trying to capitalise on their comparative advantage in relation to a particular type of knowledge, clientele or labour market linkages (Clark 1998). This may result in specific configurations of external activities and their effects across different types of the university and across different locations (see Van Looy et al. 2003, 2011).

The existing literature on the entrepreneurial university provides some important insights into the patterns of university knowledge flows at different geographical levels (Jacob et al. 2003; Klofsten and Jones-Evans 2000; D'Este and Iammarino 2010; Audretsch et al. 2012). It indicates that knowledge transfer from the university to industry tends to be geographically localised, with the extent of localisation being strongly contingent on academic discipline and the technology involved (Abramovsky et al. 2007; Acosta and Coronado 2003; Thompson and Fox-Kean 2005; Nomaler and Verspagen 2008; Audretsch et al. 2012). Much of this literature is primarily concerned with innovation and research intensity metrics. When measured in economic terms, the evidence on localised knowledge spillovers is mixed. Although proximity to a university with a strong research output can be a significant factor of the economic performance of firms (Audretsch and Lehman 2006), a few studies indicate clear "leaks" in the pipeline between university research and economic success of local industries and firms (Bania et al. 1993; Beeson and Montgomery 1993; Lofsten and Lindelof 2005; Siegel et al. 2003; Guerrero et al. 2014). Similarly, little evidence exists on the geographical extent of universities' entrepreneurial engagement (local/regional/national/international) and whether different types of universities assume entrepreneurial roles with different geographical reach. The higher education policies of the government as well as the market competition is likely to play a crucial role in determining the geographical reach of the entrepreneurial activities of universities and lead to a certain amount of specialisation for universities with different institutional configurations.

The observed limits in translating university research into the tangible economic performance can be due to the presence of different filters related to both the individual characteristics of academics, and the institutional environment within the university
(Guerrero and Urbano 2014; Guerrero et al. 2014; Mueller 2006). They can also be related to the ability of non-academic players such as firms and individuals to identify, execute and exploit entrepreneurial opportunities (Mueller 2007; Acs et al. 2009), as well as the extent to which an overall institutional context is conducive to entrepreneurship (Audretsch 2014; Acs et al. 2014). Within this framework, higher levels of research intensity and investment in new knowledge are expected to lead to improved economic performance, with entrepreneurial thinking, skills and practices being an enabling factor of this effect (Mueller 2006; Audretsch and Keilbach 2009).

What remains overlooked is the pattern of entrepreneurial activities of the teaching-led universities. Although these may invest less into the creation of new knowledge, they still represent an important source of talent, expertise and support for entrepreneurial thinking and action through formal and informal channels (Abreu and Grinevich 2013). Historically, these institutions tend to be more business facing, providing teaching, consulting, training and testing facilities in response to the demands of local industries and firms (Tiffin and Kunc 2011). Some of these institutions position themselves as pro-active technology cluster anchors, moving from incentivising formal commercialisation activities to promoting social and entrepreneurial capital (Calzonetti et al. 2012; Braunerhjelm and Helgesson 2006). Therefore, the emergence and evolution of the notion of the entrepreneurial university can no longer be considered in isolation from the evidence on increasingly important entrepreneurial activities undertaken by the less research-intensive universities.

\section{Conceptual framework and hypotheses}

The outcomes of the entrepreneurial university manifest themselves through diverse entrepreneurial practices of its individual members (Ding and Choi 2001; D'Este and Patel 2007; Kirby et al. 2011; Urbano and Guerrero 2013; Abreu and Grinevich 2013). The literature suggests that different configurations of entrepreneurial practices may be path dependent and reflective of the organisational heritage of the university (Clark 1998). For instance, Bronstein and Reihlen (2014) distinguish between four entrepreneurial university archetypes: research-driven, industry-driven, 
service-oriented and commercialisation-focussed, each capturing the deep institutional embeddedness of entrepreneurial activities. Separately, Guerrero et al. (2014) adopt an institutional economics approach (North 1990, 2005) to develop a model of entrepreneurial university activities shaped by formal and informal university environments and structures. Urbano and Guerrero (2013) combine this approach with a resource-based perspective to include into the model "internal" factors of entrepreneurial activities such as human, financial and physical capital, status and prestige, and networking capabilities.

Indeed, institutional theory represents a powerful theoretical perspective, which has been increasingly used for examining entrepreneurial practices in different contexts (Manolova et al. 2008; Busenitz et al. 2000; Hwang and Powell 2005). It is traditionally concerned with the mechanisms by which structures and rules provide authoritative guidelines and meaning for social behaviour (Scott 2005, 2014). It argues that the actions of various individual actors and organisations, such as entrepreneurs and start-ups, are constrained in the sense that they have to comply with the institutional environment in order to gain legitimacy and gain support (Scott and Meyer 1991; Scott 2005; Manolova et al.2008; Ahlstrom and Bruton 2002). Scott's (1995, 2014) typology of institutional pillars has become the dominant conceptual framework for analysing the impact of institutions on organisations and organisational players (Yamakawa et al. 2008; Bruton et al. 2005; Manolova et al. 2008). It distinguishes between the regulative, normative and cognitive pillars as the vital ingredients of institutions. The regulative dimension is related to codified rule settings and enforcement at organisational and societal levels. In this conception, regulatory processes involve the capacity to establish rules, monitor conformity and develop sanctions if necessary (Scott 2014). The normative dimension refers to professional values, commitments, roles and conventions, which are often tacit and informal. The emphasis here is on normative rules that introduce prescriptive, evaluative and obligatory dimension into institutional and social life (Scott 2014). As well as imposing constraints on human behaviour, they empower and enable social action. The cognitive dimension has to do with shared interpretation of certain situations and shared logics of action. These refer to internal interpretative processes that are shaped by external cultural frameworks. Translating institutional theory to the domain of entrepreneurial universities entails us a multi-level conceptualisation and in-depth examination of mandated specifications, including laws, governance and monitoring systems at the regulative pillar level (see Foss and Gibson 2015). These relate to how or to what extent university rules on intellectual property, governance, business models of technology transfer offices and related regulations encourage or discourage academic entrepreneurship. The normative pillar pertains to university cultures, departmental cultures (differences between STEM and non-STEM departments for example), and their surrounding contexts, which may facilitate or inhibit entrepreneurship. This pillar underscores importance of understanding motivation for, or resistance to, behavioural and institutional change (Foss and Gibson 2015) towards academic entrepreneurship. Finally, cognitive pillar encompasses academic predispositions and symbolic value as models for individual behaviour regarding the individual academic acceptance of, and engagement in, entrepreneurship (ibid). Disciplinary backgrounds, seniority, prior experience and knowledge as cultural capital in amalgamated form (Karataş-Özkan and Chell 2015) influence academic entrepreneurship.

Academics are subject to multiple and often conflicting institutional influences arising from the different roles and identities they may assume at the level of the university, academic discipline, professional status and generational cohort. The actions of academics as individual-level actors are crucial to understand as they manage competing and often conflicting logics by developing structures and systems to enable their academic practice. Conflicting institutional logics co-exist and are sustained by policy discourse and practices in the field of higher education. We adopt an institutional theory approach and propose an analytical framework where differences in patterns of the entrepreneurial activities are explained by regulative, normative and cognitive elements of academic institutions. According to the institutional logics perspective (Thornton et al. 2013), individual actors, when facing conflicting institutional pressures, are not only constrained and regulated by institutional rules and norms, but also they are empowered to innovate, transform, combine and make strategic use of different institutional demands. Essentially, individual actors avoid the complexity of conflicting 
institutional expectations by compartmentalising and integrating norms from different institutional orders. This allows the actors to achieve legitimacy and simultaneously protect strategic goals, while avoiding a cognitive conflict. Most of the studies in this area are performed at the organisational level, with the institutional logics scholars calling for more research on the individual level of analysis (Thornton et al. 2013; Lounsbury and Beckman 2015).

\subsection{Hypotheses}

In relation to the regulative dimension, the literature on research commercialisation highlights the positive effects of having in place formal mechanisms and structures such as technology transfer offices (TTOs), intellectual property rights protection (IP) and incentive measures (O'Shea et al. 2005; Kirby 2005; Grimaldi and Grandi 2005). However, in some instances, rigid administrative rules enforced by TTOs and inflexibility of university units can stifle commercialisation activities (Siegel et al. 2004; Thursby et al. 2001). Overall, organisational and governance structures and codes aimed at reducing bureaucracy and improving coordination are strongly linked to increased levels of technology commercialisation (Bercovitz et al. 2001). Research-intensive universities tend to have, for historical reasons, dedicated knowledge transfer structures, with particular emphasis being placed on licensing, spin-outs and joint research projects with industry (Bronstein and Reihlen 2014). As the complexity of these structures increases over time and with the growing size of the university, they may exhibit a weakened capacity to manage knowledge transfer and lose their connections with the changing scientific and entrepreneurial developments. The impact of this constraint can, however, be lessened in institutions with a strong reputation for research excellence (Clark 1998). In contrast, peripheral or less well-known research institutions, with a smaller size may have an advantage when it comes to making and enforcing administrative decisions efficiently, due to a younger TTO organisation that is recently built to address the most recent needs of the academic and entrepreneurial environments. Overall, UK-specific studies indicate that TTO departments at UK universities often fail to exert a strong positive influence on the entrepreneurial engagements of universities, even though there is little comparison on whether this applies to both teaching-led and research-intensive universities (Chapple et al. 2005; Siegel et al. 2008). Hence, we start with an initial hypothesis that as follows:

Hypothesis 1 Regulative influences do not exert a strong effect on the entrepreneurial engagement of research-intensive and teaching-led universities.

In relation to the normative dimension, importance of network ties, commitments and repertoires of collective action is often emphasised in scholarly debates (see Scott 2014). This involves conceptions of appropriate goals and activities for specified social positions. Two interlocking types of logics are in operation in defining normative constituents of institutions: logic of appropriateness and logic of instrumentality. The interplay between the two leads to societal legitimisation (of an activity or practice). Translating these two entrepreneurial expressions and engagements of academics, we argue that academic values, peer group expectations and pressure, professional roles as well as departmental cultures affect entrepreneurial activities. Shared experiences and associated professional objectives might bring about positive institutional agency (Nillsson 2015), which can be instrumental in fostering entrepreneurial practices. In the university context, these may also be related to normative pressures coming from an academic department, professional network or institution as a whole. Amongst important normative influences can be "role models" (Krueger et al. 2000), represented by academics, who have prior entrepreneurial experiences (Mosey and Wright 2007; O'Shea et al. 2007). Related to this is Clark's (1998) argument about the need for the entrepreneurial university to blend academic and managerial points of view, by making individuals and collegial groups have a strong role in central steering groups. The literature indicates that research-intensive universities are better positioned to host and blend star scientists, top industry experts, and flagship entrepreneurs (Zucker and Darby 1996; Bronstein and Reihlen 2014), who tend to collaborate within national and international networks. These networks are crucial in conditioning the social and professional relations of actors through their associated identification or disidentification (Thompson and Willmott 2016). Thus, we suggest that normative pressures play an important role in the entrepreneurial engagements of universities as follows: 
Hypothesis 2 Normative factors exert a strong influence on the entrepreneurial engagement of research-intensive and teaching-led universities.

Interplay of ascribed meanings, belief sets and emotions form the core of cognitive dimension (Voronov and Vince 2012; Moisander et al. 2016). In relation to this aspect, the literature discusses the influence of predispositions towards entrepreneurial behaviour (Karataş-Özkan 2011; Klapper and Refai 2015). These predispositions are influenced by beliefs about personal gains and losses, which may result from entrepreneurial behaviour, and the impacts may not be entirely about economic profits (Mars and Rios-Aguilar 2010), with other considerations such as reputation, prestige, recognition, ownership and prizes being in place, and often referred to as symbolic capital (Bourdieu 1974; Hagstrom 1966; van Rijnsover et al. 2008). Human capital is commonly associated with career status (Allen et al. 2007), and is considered relevant in configuring cognitive controls (Guerrero and Urbano 2014). Social capital manifests itself in the ability to access diverse knowledge and finance resources due prior entrepreneurial and industry experiences, and multiple roles performed (Mosey and Wright 2007; Dietz and Bozeman 2005). A large body of the literature indicates that individual characteristics, attitudes and controls are amongst the most important predictors of entrepreneurial activities of academics (Louis et al. 1989; Klofsten and Jones-Evans 2000; Ding et al. 2006; Azoulay et al. 2007; Veciana and Urbano 2008). The role of the cognitive dimension is further highlighted by the institutional logics approach, which notes that seemingly identical institutional structures populated with different actors can result in different meanings and institutional effects (Thornton et al. 2013). Therefore, different meanings attached to similar rules, routines and resources may lead to different behavioural responses and strategies. Our point is that cognitive scripts, schemas and behaviours of individuals, whose evaluation and acceptance of entrepreneurship based on knowledge and skill (Karataş-Özkan et al. 2014), influence their entrepreneurial engagement. Central role played by the socially mediated construction of a common framework of meanings (Scott 2014) should be taken into account for understanding entrepreneurial activity. Some of the decision processes involved in creating a new venture, designing the structure of the organisation and managing relationships with a range of stakeholders (particularly with funders) (Tolbert et al. 2011) involve cognitive (as well as relational) processes of sense-making. By applying this reasoning in the entrepreneurial university context, we suggest:

Hypothesis 3 Cognitive influences exert a strong effect on the entrepreneurial engagement of researchintensive and teaching-led universities.

Finally, it is important to consider the role of UK higher education policy as a factor that shapes the entrepreneurial engagement patterns for the two types of universities. One of the strongest trends in the UK higher education policies is a growing emphasis on the national and international-rather than local and regional-scope of universities (Witty Review 2013; Cochrane and Williams 2013). Even though some funding has been allocated for the local and regional activities of UK universities, the strongest policy emphasis in the last decade has been on national and international excellence and reputation (captured by national and international university league tables as well as the Research Excellence Framework) rather than the local/regional roles and contributions of universities (Russell Group 2015). These policy directions are likely to lead to significant disparities in the geographical focus of entrepreneurial engagement amongst research-intensive and teaching-led universities. The larger size and resources of research-intensive universities along with their longer history of existence within the UK's socio-economic system provides them a significant advantage for aligning their entrepreneurial engagement activities more effectively with national and international opportunities. Teaching-led universities, on the other hand, may find it more manageable to engage with the local and regional entrepreneurial opportunities as these tend to be less resource-intensive than national and international ones. In particular, the growing marketization of the UK universities and the competition between them could enhance the geographical specialisation of UK universities where research-intensive and teaching-led universities focus on the international/national and regional/local entrepreneurial engagement activities respectively (Boucher et al. 2003; Lebeau and Cochrane 2015). Hence, we suggest:

Hypothesis 4 Research-intensive universities are more likely to engage with national/international entrepreneurial opportunities while teaching-led 
universities are more likely to engage with local/ regional entrepreneurial opportunities.

\section{Data and methods}

\subsection{Data sources}

Our analysis combines variables at the level of the individual academic with university-level variables in order to provide a comprehensive coverage of the different elements of the three institutional pillars (i.e. regulative, normative and cognitive). The academiclevel data are available from a survey conducted over 2008-2009 as part of a wider ESRC-funded research project (UK-HEI). ${ }^{1}$ The survey was administered through an online web-survey tool, and was sent to all UK-based academics (i.e. 126,120 academics in total) whose contact details were publicly listed. ${ }^{2}$ The final sample was 22,556, which also includes a number of paper-based questionnaires, for an overall response

\footnotetext{
1 The research project titled "Industry-University Knowledge Exchange: Demand Pull, Supply Push and the Public Space Role of Higher Education Institutions in the UK Regions" was conducted at University of Cambridge and funded by the UK's Economic and Social Research Council (ESRC) in collaboration with Scottish Funding Council (SFC), Department for Employment and Learning in Northern Ireland (DEL), Higher Education Funding Council for England (HEFCE) and Higher Education Funding Council for Wales (HEFCW). The project was designed with the broad objective of identifying the factors that affect the incidence, form, effectiveness and regional impact of knowledge exchange activities between the business and higher education sectors in the UK. More information about the broader project is available in Abreu et al. (2009).

${ }^{2}$ No publicly available database that provides contact details for this sampling frame was available. Therefore, a list of all UK higher education institutions was compiled based on data from three public institutions: (1) Higher Education Statistical Agency (HESA), (2) Universities, UK and (3) Higher Education Funding Councils of England, Wales, Scotland and the Northern Ireland Department for Employment and Learning. We then manually collected the contact details of all academic staff active in teaching and/or research from the websites of all of these institutions covering all departments and faculties within each university. This directory of contact details was the sampling frame to which we addressed a web-based questionnaire. Difficulties with web access led to the exclusion of four smaller specialist HEIs from the sampling frame. The final sample includes all grades of staff; $19 \%$ are Professors, $30 \%$ are Readers, Senior Lecturers, or Senior Researchers; $42 \%$ are Lecturers, Researchers or Teaching or Research Assistants, and $9 \%$ are other grades of staff.
}

rate of $17.8 \% .^{3}$ The survey covers entrepreneurial activities ranging from the creation of spin-outs, joint research with external organisations, testing and prototyping, to informal advice and public lectures for the community. It also includes questions on the culture and ethics of academic entrepreneurship, and the geographical scope of entrepreneurial activities. The questions in the survey refer to the 3 -year period prior to the survey (i.e. 2005-2008). This period corresponds to the third round of Higher Education Innovation Fund (HEIF) in the UK whereby all universities were allocated funds for knowledge transfer as part of a competitive scheme that aimed to increase the university capabilities to respond to the needs of the business and community (Gilman and Serbanica 2015). HEIF is one of the legislative and funding programmes to foster enterprise culture in the UK. In alignment with two other major programmes, namely the University Challenge and Science Enterprise Challenge, the HEIF stimulated the commercialisation of university-based research and other knowledge exchange activity such as public-private partnerships (Lockett et al. 2005; Foss and Gibson 2015).

For the construction of university-level variables, we use institutional data provided by the Higher Education Statistics Agency (HESA), taken from institution-level surveys. Control variables, such as the index of specialisation and centralisation, were constructed using data from the Resources of Higher Education Institutions 2006-2007 (RHEI). Data on institutional rules and regulations were taken from the Higher Education-Business and Community Interaction Survey 2007/08 (HE-BCI) (Resources of Higher Education Institutions) (http://www.hefce.ac.uk/kess/ hebci/).

We utilise a dichotomous categorisation of "research-intensive" versus "teaching-led" universities in our empirical investigations. Research-intensive universities include all universities that were members of the Russell Group, an umbrella organisation of research-intensive universities, over the time period covered by the analysis, in addition to institutions that were members of the 1994 Group of (mainly) smaller and more specialised research-intensive universities, which subsequently came to be part of the Russell

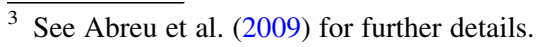


Group. ${ }^{4}$ There are 150 institutions included in the analysis, including 24 Russell Group research-intensive universities, and 126 teaching-led universities. The research-intensive character of Russell-Group universities is evident in major research-based metrics. Despite accounting for less than $15 \%$ of the UK higher education institutions, they accounted for $60 \%$ of all doctorates awarded and $74 \%$ of all UK universities' research grant income in 2012-2013. Additionally, Russell Group affiliated research outputs that were assessed to be "world-leading" in the UK's Research Assessment Exercise in 2008 was twice as many as those in the remaining universities (Russell Group 2015). The remaining UK universities, defined as teaching-led universities, on the other hand, include those that have a more balanced portfolio of teaching, research and enterprise as well as those that focus more on teaching.

\subsection{Methods}

The analysis consists of three parts. The first part is a descriptive study of the patterns of engagement in a range of entrepreneurial activities by academics at research-intensive and teaching-led institutions. We consider a wide range of formal and informal entrepreneurial activities in order to construct a broad basis of definition on entrepreneurial practices. Formal entrepreneurial practices that we cover include licensing and spin-out activities and are the ones that are commonly used by the literature to capture the more traditional and tangible entrepreneurial practices of universities (Rothaermel et al. 2007; Shane 2004; Guerrero and Urbano 2014; Markman et al. 2005). In order to go beyond the formal practices, we include activities suggested in the literature (see Lester 2005 and Gilman and Serbanica 2015 for a review), related to broader knowledge exchange practices of the universities. Focusing on the problem-solving activities, which are most likely to encapsulate both innovation and entrepreneurial thinking aspects of knowledge exchange, we consider how the patterns of engagement vary by geography (local, regional, national and international) between the two groups of universities.

\footnotetext{
${ }^{4}$ The results are virtually identical if using a numerical definition of research intensity based on total research income above the median for all institutions, or $17.6 \%$ of total income.
}

In the second part of the analysis, we study the determinants of entrepreneurial activities in more detail through the lens of institutional theory. We first focus on "licensing and spin-outs", which are most tangible and commonly used measures of academic contribution to innovation, and secondly consider "problem-solving" activities, which cover a wider range of softer academic activities supporting entrepreneurial endeavours (such as joint research, contract research, research consortia, consultancy, informal advice, and joint publications). ${ }^{5}$ We run a series of probit regressions, where the dependent variable is respectively (a) licensing or spin-out (a dichotomous variable measuring whether an individual academic has been involved in either a spin-out or licensing of research outputs), and (b) problem-solving (a dichotomous variable measuring whether the academic has been involved in any of a range of problem-solving activities; see Table 1 for full details on these activities). ${ }^{6} \mathrm{We}$ run separate regressions for academics in teaching-led and research-intensive universities in order to compare the relevance of the determinants of entrepreneurship in these two settings.

In the final part, we disentangle the source of differences in the geography of engagement in problem-solving activities, by type of university. We focus on problem-solving activities because of their importance for innovation and entrepreneurship policy, and because their geographical scope varies significantly by type of university. We use a Blinder-Oaxaca decomposition model (Blinder 1973; Oaxaca 1973) to disaggregate the overall differences in entrepreneurial engagement between academics from teaching-led and research-intensive universities. After considering the institutional determinants of problem-solving activities in the second part of our analysis, this decomposition tool allows us to gain a better understanding of the degree to which the different patterns

\footnotetext{
5 See Gilman and Serbanica (2015) for a review of the literature on channels of knowledge transfer beyond licensing and spinout activities.

6 The geographical scale of the problem-solving activities variable is "national", i.e., within the UK but beyond the immediate region The reason for choosing the "national" dimension is that at this geographical scale the difference between the degree of engagement in teaching-led and researchintensive universities is small, so we are able to focus on the overall effect of the determinants. We disentangle the geography in the following part of the analysis.
} 
Table 1 Entrepreneurial practices by type of university (sample means and $t$ tests)

\begin{tabular}{|c|c|c|c|}
\hline & $\begin{array}{l}\text { Teaching-led } \\
\text { (mean) }\end{array}$ & $\begin{array}{l}\text { Research int. } \\
\text { (mean) }\end{array}$ & $\begin{array}{l}\text { Difference } \\
(t \text { test })\end{array}$ \\
\hline \multicolumn{4}{|l|}{ Licensing and spin-out activities } \\
\hline Licensing and spin-outs & 0.053 & 0.066 & $-0.014 * * *$ \\
\hline Licensing & 0.034 & 0.048 & $-0.014 * * *$ \\
\hline Spin-out & 0.028 & 0.033 & $-0.005^{* *}$ \\
\hline \multicolumn{4}{|l|}{ Problem-solving activities } \\
\hline Hosting of personnel from external organisations on a short- or long-term basis & 0.080 & 0.091 & $-0.012 * * *$ \\
\hline Secondment on a short- or long-term basis to an external organisation & 0.023 & 0.025 & -0.001 \\
\hline Joint research with external organisations (original work undertaken by both parties) & 0.216 & 0.278 & $-0.062 * * *$ \\
\hline $\begin{array}{l}\text { Contract research with external organisations (original work undertaken by academic } \\
\text { partner only) }\end{array}$ & 0.168 & 0.200 & $-0.032 * * *$ \\
\hline Consultancy services (no original research undertaken) & 0.195 & 0.203 & -0.008 \\
\hline Participating in research consortia with external organisations & 0.165 & 0.209 & $-0.044 * * *$ \\
\hline Providing informal advice on a non-commercial basis & 0.264 & 0.306 & $-0.042 * * *$ \\
\hline Prototyping and testing for external organisations & 0.046 & 0.048 & -0.001 \\
\hline \multicolumn{4}{|l|}{ Geographical reach of problem-solving activities } \\
\hline Local level & 0.322 & 0.293 & $0.029 * * *$ \\
\hline Regional level & 0.410 & 0.331 & $0.080 * * *$ \\
\hline National level & 0.489 & 0.547 & $-0.057 * * *$ \\
\hline International level & 0.374 & 0.497 & $-0.122 * * *$ \\
\hline
\end{tabular}

* Significant at $10 \%$ level, ** significant at $5 \%$ level, *** significant at $1 \%$ level

of entrepreneurial engagement between the two types of universities result from (1) endowments: the differences in the observable extrinsic characteristics included as explanatory variables in the probit model and (2) coefficients: the unobservable or unmeasured intrinsic characteristics and attitudes of the academics operating in the two distinct types of institutional settings, as well as (3) the interaction between 1 and $2 .^{7}$ While (1) measures the share of differences in entrepreneurial engagement that can be attributed to the observed institutional factors included in our model, (2) could be interpreted as the share of differences that arise due to unobserved factors shaping the behavioural responses of academics in both institutions. The latter captures the impact of various factors that we are not able observe/account

\footnotetext{
7 The interaction effects are included to allow for an interaction between (1) and (2) and do not constitute the focus of our analysis.
}

for (e.g. the broader national and regional policies related to university-industry interactions and the perception of different types of universities in the eyes of policy makers and the potential collaboration partners) as potential determinants of academics' behavioural responses. This decomposition method, which originated from labour economics, has more recently been implemented in entrepreneurship studies that examine the impact of factors such as gender, race, ownership, ethnicity and immigration status on various forms of entrepreneurial activities (Block et al. 2015; Clark and Drinkwater 2010; Wagner 2008; He 2008; Lofstrom and Bates 2009 amongst others).

Technically, the Blinder-Oaxaca decomposition operates with two groups, Group 1 (the reference group, with the highest outcome) and Group 2; and investigates the differences in the expected mean of the outcome variable (i.e. engagement in problemsolving activities) between the two groups. In the discussion in Sect. 5.3, we always take Group 1 to be 
the group with the highest outcome (as this results in a more intuitive explanation). The reference group (Group 1) is, therefore, teaching-led institutions for local and regional geographies (columns 1 and 2 in Table 4), and research-intensive universities for national and international geographies (columns 3 and 4 in Table 4). Our implementation of the BlinderOaxaca model follows Fairlie (1999) who generalised the technique to the case of discrete choice models (including the probit model) and we use the latest version of the Stata command "oaxaca", which is extended to cover probit models, for estimating the models in Table 4 (Jann 2008).

\subsection{Variables included in the analysis}

The dependent variables are discrete and capture whether an individual academic has engaged in a given entrepreneurial activity between 2006 and 2008. We focus on two types entrepreneurial practices: (a) licensing and spin-outs, and (b) problem-solving activities. In keeping with our conceptual framework, the explanatory variables are subdivided into three categories: regulative, normative and cognitive dimensions. Regulative dimension is proxied by three university-level variables: (1) the presence of a Technology Transfer Office (TTO) at the University and the university's imposition on academics to report IP emerging from (2) inventions and (3) arts and literature. These three variables aim to capture the impact of a formal regulatory environment surrounding university's entrepreneurial practices and measure how strictly IP related issues are regulated and monitored by the university. The normative dimension is captured through three distinct variables: (1) average use of TTO at the university level, (2) proportion of staff with managerial experience and (3) importance of business engagement. All three university-level variables capture relevant dimensions of norms that govern the entrepreneurial engagement of academics. Respectively, these variables reflect (1) the habits/routines around involvement of TTOs in entrepreneurial engagements, (2) the degree to which staff at a given university is expected to develop managerial capabilities in addition to academic capabilities and (3) the degree to which entrepreneurial engagement plays a significant role in the promotion of academic staff. Finally, the cognitive dimension is proxied by a range of academic-level variables, capturing the prior business and academic experience of individuals. Business experience is proxied through a range of dummy variables that measure whether the individual has (1) started a SME, worked for (2) a SME, (3) a large business, (4) the government or (5) a charity organisation. The academic experience is proxied via seniority of the individual captured by the academic job titles of Professor, Associate Professor, Lecturer and Research Fellow in addition to proxies that reflect the nature of the research the individual undertakes (i.e. basic, applied and useinspired). Additionally, a number of institution-level variables are included as control factors in order to account for other determinants of entrepreneurial engagement. A detailed list of the variables included in the analysis, with corresponding data sources, is provided in Table 5. In the Blinder-Oaxaca decomposition, we focus on "problem-solving activities" and consider the geography at which these activities take place. Geographical classification is built on selfdeclared information on whether the non-academic partner organisation is located in the "local area" (i.e. within 10 miles), the "region" (i.e. outside of the local area, but within the NUTS 2 region), "nationally" (i.e. outside of the region, but within the UK), or "internationally" (i.e. outside of the UK).

\section{Results and analysis}

\subsection{Descriptive analysis}

Table 1 shows how engagement in entrepreneurial activities varies by type of university. An initial examination reveals that the research-intensive universities have distinctively higher rates of licensing and spin-out activities but the differences between the two universities are less visible and often insignificant for softer forms of entrepreneurial engagement grouped under the broad title of "problem-solving activities". A closer look at the geographical reach of problem-solving activities suggests that there are significant differences between the two types of universities: academics at teaching-led institutions have higher rates of local and regional engagement, indicating that they are better embedded in local and regional business networks, while academics at research-intensive universities are more active at the national and international levels. 
Table 2 provides descriptive statistics for the variables included in the analysis. Research-led institutions have significantly higher entrepreneurial engagement rates measured by both dependent variables. In terms of the regulative structure, teaching-led universities are more likely to enforce IP for outputs in the arts and have a TTO department while researchintensive institutions are more likely to enforce IP for inventions.
The differences in terms of the normative dimension are also significant. For instance, academics in teaching-led institutions are more likely to perceive that engagement with business and industry is very important for career advancement, and they are more likely to use the TTO, while academics at researchintensive universities are more likely to merge academic and managerial responsibilities. Finally, in terms of the cognitive profile, academics at teaching-

Table 2 Descriptive statistics for the variables included in the analysis, by type of university (sample means and $t$ tests)

\begin{tabular}{|c|c|c|c|}
\hline & Teaching-led universities & Research int. universities & Difference $(t$ test $)$ \\
\hline \multicolumn{4}{|l|}{ Dependent variables } \\
\hline Licensing and spin-outs & 0.053 & 0.067 & $-0.014 * * *$ \\
\hline Problem-solving activities & 0.489 & 0.547 & $-0.057 * * *$ \\
\hline \multicolumn{4}{|l|}{ Independent variables } \\
\hline \multicolumn{4}{|l|}{ Regulative dimension } \\
\hline TTO department & 0.597 & 0.199 & $0.398 * * *$ \\
\hline Requires IP for inventions & 0.748 & 0.816 & $-0.068 * * *$ \\
\hline Requires IP for arts/literature & 0.256 & 0.043 & $0.214 * * *$ \\
\hline \multicolumn{4}{|l|}{ Normative dimension } \\
\hline Average use of TTO & 0.254 & 0.196 & $0.058 * * *$ \\
\hline Proportion managers & 0.473 & 0.475 & $-0.002 * *$ \\
\hline Importance of business engagement & 0.097 & 0.061 & $0.037 * * *$ \\
\hline \multicolumn{4}{|l|}{ Cognitive dimension } \\
\hline Respondent age $(<30)$ & 0.047 & 0.075 & $-0.028 * * *$ \\
\hline Respondent age (30-39) & 0.228 & 0.313 & $-0.085 * * *$ \\
\hline Respondent age (40-49) & 0.305 & 0.272 & $0.032 * * *$ \\
\hline Respondent age $(>50)$ & 0.420 & 0.340 & $0.081 * * *$ \\
\hline Basic research & 0.222 & 0.308 & $-0.085 * * *$ \\
\hline User inspired research & 0.270 & 0.302 & $-0.032 * * *$ \\
\hline Applied research & 0.461 & 0.361 & $0.100 * * *$ \\
\hline Professor & 0.180 & 0.242 & $-0.062 * * *$ \\
\hline Assoc. professor & 0.412 & 0.234 & $0.178 * * *$ \\
\hline Lecturer & 0.259 & 0.224 & $0.036 * * *$ \\
\hline Research fellow & 0.113 & 0.246 & $-0.132 * * *$ \\
\hline Previously owned a SME & 0.174 & 0.106 & $0.068 * * *$ \\
\hline Previously employee of a SME & 0.290 & 0.197 & $0.092 * * *$ \\
\hline Previously employee of a large firm & 0.292 & 0.218 & $0.074 * * *$ \\
\hline Previously employee of a public organisation & 0.371 & 0.289 & $0.082 * * *$ \\
\hline Previously employee of a charity & 0.177 & 0.131 & $0.047 * * *$ \\
\hline \multicolumn{4}{|l|}{ Control variables } \\
\hline Degree of centralisation & 0.160 & 0.095 & $0.065 * * *$ \\
\hline Index of specialisation & 0.151 & 0.120 & $0.031 * * *$ \\
\hline Proportion of employees younger than 40 & 0.275 & 0.388 & $-0.113 * * *$ \\
\hline Gender of respondent (female $=1$ ) & 0.423 & 0.373 & $0.049 * * *$ \\
\hline
\end{tabular}

* Significant at $10 \%$ level, ** significant at $5 \%$ level, *** significant at $1 \%$ level 
led universities are more likely to be older, hold junior positions (other than professor), carry out applied research, and have previous business experience.

\subsection{Regression results}

We start by considering how the variables discussed in the previous section correlate with the likelihood of engaging in (a) licensing and spin-outs, and (b) problem-solving activities, by type of university. We do this by running probit regressions at the level of the individual, but including all of the individual and university level variables discussed above. The results, displaying marginal effects, are shown in Table 3.

In terms of the regulative dimension, our findings offer support to Hypothesis 1 as regulative factors fail to exert a strong effect on either type of entrepreneurial engagement. Prior literature that flags the low efficiency levels at UK universities' TTO departments (Chapple et al. 2005; Siegel et al. 2008) provides a plausible explanation to why the TTOs fail to promote entrepreneurial engagements. The negative sign of the "TTO department" variable for the problem-solving activities of research-intensive universities further alludes to the bias away from softer and less formal types of entrepreneurial engagement within the regulative environments of research-intensive universities. Strict monitoring of intellectual property rights, likewise, fails to promote entrepreneurial engagement in most cases, with the exception of problem-solving activities within teaching-led universities. The rigid and bureaucratic IP regulations practiced by TTOs are often perceived by academics in research-intensive universities as a constraint on the avenues of engagement with external partners (Audretsch 2014). Given the less complex processes in place and/or the lower individual profiles, the rules requiring IP protection in teaching-led institutions are associated with a higher likelihood of engagement in problem-solving activities for academics in these institutions.

The results support Hypothesis 2 with various caveats. Firstly, the findings suggest that normative factors exert a weaker influence on licensing and spinout activities, as compared to problem-solving activities. The strongest result emerging in this area relates to the negative influence of the TTO dominance within the university (proxied by the average use of TTO) on the problem-solving activities of both types of universities. This can be related to the strong bias in favour of formal types of entrepreneurial engagement and a potential discrimination against softer forms of engagement in TTOs (Audretsch 2014; D'Este and Perkmann 2011; Perkmann et al. 2013). Secondly, an emphasis on business engagement appears to promote problem-solving activities in teaching-led universities while having no significant influence for researchintensive institutions. This may suggest that normative expectations related to the academic career progression tend to be more strongly aligned with the third mission deliverables in teaching-led institutions. Finally, we note that a higher level of managerial engagement is associated with greater involvement in licensing and spin-out activities in research-intensive universities and greater involvement in problemsolving activities in teaching-led universities. This suggests that institutional attempts to develop managerial capabilities may help to support the entrepreneurial engagement of academics in the activities for which their institution possesses a relative competitive advantage (i.e. licensing and spin-out activities for research-intensive universities and problem-solving activities teaching-led universities).

In terms of the cognitive dimension, our results support Hypothesis 3 with most variables reflecting the work related experiences of academics exerting a significant effect across both types of activities and institutions. The age variable, which can be viewed as a broad proxy for experience, has a positive influence on entrepreneurial engagement. In particular, older academics in research-intensive universities appear to play a more significant role in driving entrepreneurial activities. This result is further confirmed in the findings highlighting the significant role of senior academics (proxied by the "professor" variable) for driving both types of entrepreneurial engagement. While seniority is also associated with greater involvement in problem-solving activities, the effect is more wide-ranging, with a positive effect observed for senior academics below the level of "professor" (relative to the most junior academics in the base category). The nature of the academic research also exerts a significant effect, with applied research activities motivating both types of entrepreneurial engagement and use-inspired research motivating engagement in problem-solving activities. It should be noted that basic research activities with no obvious commercial applications do not play a significant role in explaining the entrepreneurial engagements of 
Table 3 Determinants of entrepreneurial activities at the national level, by type

\begin{tabular}{|c|c|c|c|c|}
\hline & $\begin{array}{l}\text { Licensing and spin-outs: } \\
\text { Teaching led institutions }\end{array}$ & $\begin{array}{l}\text { Licensing and spin-outs: } \\
\text { Research-intensive } \\
\text { institutions }\end{array}$ & $\begin{array}{l}\text { Problem-solving: } \\
\text { Teaching led } \\
\text { institutions }\end{array}$ & $\begin{array}{l}\text { Problem-solving: } \\
\text { Research-intensive } \\
\text { institutions }\end{array}$ \\
\hline \multicolumn{5}{|l|}{ Regulative dimension } \\
\hline TTO department & $\begin{array}{r}-0.001 \\
(0.003)\end{array}$ & $\begin{array}{r}-0.004 \\
(0.005)\end{array}$ & $\begin{array}{c}0.012 \\
(0.010)\end{array}$ & $\begin{array}{l}-0.047 * * * \\
(0.016)\end{array}$ \\
\hline Requires IP for inventions & $\begin{array}{c}0.004 \\
(0.004)\end{array}$ & $\begin{array}{r}-0.004 \\
(0.006)\end{array}$ & $\begin{array}{l}0.045^{* * *} \\
(0.013)\end{array}$ & $\begin{array}{c}0.004 \\
(0.018)\end{array}$ \\
\hline Requires IP for arts/literature & $\begin{array}{r}-0.001 \\
(0.004)\end{array}$ & $\begin{array}{r}-0.006 \\
(0.008)\end{array}$ & $\begin{array}{l}0.049 * * * \\
(0.013)\end{array}$ & $\begin{array}{c}0.006 \\
(0.030)\end{array}$ \\
\hline \multicolumn{5}{|l|}{ Normative dimension } \\
\hline Average use of TTO & $\begin{array}{c}0.013 \\
(0.018)\end{array}$ & $\begin{array}{c}0.000 \\
(0.036)\end{array}$ & $\begin{array}{l}-0.202 * * * \\
(0.060)\end{array}$ & $\begin{array}{l}-0.457 * * * \\
(0.110)\end{array}$ \\
\hline Proportion of managers & $\begin{array}{c}0.019 \\
(0.024)\end{array}$ & $\begin{array}{l}0.159 * * \\
(0.067)\end{array}$ & $\begin{array}{l}0.364 * * * \\
(0.080)\end{array}$ & $\begin{array}{c}0.212 \\
(0.203)\end{array}$ \\
\hline $\begin{array}{l}\text { Importance of business } \\
\text { engagement }\end{array}$ & $\begin{array}{l}0.028 \\
(0.028)\end{array}$ & $\begin{array}{r}-0.016 \\
(0.084)\end{array}$ & $\begin{array}{l}0.211 * * \\
(0.097)\end{array}$ & $\begin{array}{l}0.329 \\
(0.262)\end{array}$ \\
\hline \multicolumn{5}{|l|}{ Cognitive dimension } \\
\hline Respondent age (30-39) & $\begin{array}{c}0.010 \\
(0.011)\end{array}$ & $\begin{array}{l}0.045^{* * * *} \\
(0.014)\end{array}$ & $\begin{array}{r}0.048 * \\
(0.026)\end{array}$ & $\begin{array}{l}0.072 * * * \\
(0.021)\end{array}$ \\
\hline Respondent age (40-49) & $\begin{array}{c}0.014 \\
(0.011)\end{array}$ & $\begin{array}{l}0.038 * * \\
(0.015)\end{array}$ & $\begin{array}{l}0.058 * * \\
(0.026)\end{array}$ & $\begin{array}{l}0.116^{* * *} \\
(0.023)\end{array}$ \\
\hline Respondent age $(\geq 50)$ & $\begin{array}{r}-0.000 \\
(0.010)\end{array}$ & $\begin{array}{l}0.030 * * \\
(0.014)\end{array}$ & $\begin{array}{c}0.032 \\
(0.027)\end{array}$ & $\begin{array}{l}0.091 * * * \\
(0.024)\end{array}$ \\
\hline Basic research & $\begin{array}{r}-0.012 \\
(0.009)\end{array}$ & $\begin{array}{c}-0.017 \\
(0.012)\end{array}$ & $\begin{array}{c}-0.023 \\
(0.026)\end{array}$ & $\begin{array}{c}-0.013 \\
(0.032)\end{array}$ \\
\hline User inspired research & $\begin{array}{c}0.014 \\
(0.012)\end{array}$ & $\begin{array}{c}0.016 \\
(0.016)\end{array}$ & $\begin{array}{l}0.145^{* * *} \\
(0.025)\end{array}$ & $\begin{array}{l}0.161 * * * \\
(0.030)\end{array}$ \\
\hline Applied research & $\begin{array}{l}0.027 * * \\
(0.011)\end{array}$ & $\begin{array}{c}0.029 * \\
(0.016)\end{array}$ & $\begin{array}{l}0.210^{* * *} \\
(0.024)\end{array}$ & $\begin{array}{l}0.235^{* * * *} \\
(0.030)\end{array}$ \\
\hline Professor & $\begin{array}{l}0.037 * * \\
(0.016)\end{array}$ & $\begin{array}{l}0.049 * * * \\
(0.016)\end{array}$ & $\begin{array}{l}0.337 * * * \\
(0.025)\end{array}$ & $\begin{array}{l}0.332 * * * \\
(0.022)\end{array}$ \\
\hline Assoc. professor & $\begin{array}{c}0.004 \\
(0.010)\end{array}$ & $\begin{array}{c}0.019 \\
(0.012)\end{array}$ & $\begin{array}{l}0.149 * * * \\
(0.029)\end{array}$ & $\begin{array}{l}0.220 * * * \\
(0.024)\end{array}$ \\
\hline Lecturer & $\begin{array}{c}0.002 \\
(0.010)\end{array}$ & $\begin{array}{r}-0.003 \\
(0.009)\end{array}$ & $\begin{array}{c}0.041 \\
(0.029)\end{array}$ & $\begin{array}{l}0.093 * * * \\
(0.025)\end{array}$ \\
\hline Research fellow & $\begin{array}{c}-0.002 \\
(0.010)\end{array}$ & $\begin{array}{c}-0.008 \\
(0.008)\end{array}$ & $\begin{array}{l}0.122 * * * \\
(0.029)\end{array}$ & $\begin{array}{l}0.099 * * * \\
(0.024)\end{array}$ \\
\hline Previously owned a SME & $\begin{array}{l}0.095^{* * * *} \\
(0.008)\end{array}$ & $\begin{array}{l}0.163 * * * \\
(0.014)\end{array}$ & $\begin{array}{l}0.075^{* * * *} \\
(0.014)\end{array}$ & $\begin{array}{l}0.126^{* * * *} \\
(0.017)\end{array}$ \\
\hline Previously employee of a SME & $\begin{array}{l}0.008^{* *} \\
(0.004)\end{array}$ & $\begin{array}{c}0.009 * \\
(0.005)\end{array}$ & $\begin{array}{l}0.030^{* *} \\
(0.012)\end{array}$ & $\begin{array}{l}0.031 * * \\
(0.014)\end{array}$ \\
\hline $\begin{array}{l}\text { Previously employee of a large } \\
\text { firm }\end{array}$ & 0.001 & 0.006 & 0.020 & $0.046 * * *$ \\
\hline & $(0.004)$ & $(0.004)$ & $(0.012)$ & $(0.013)$ \\
\hline
\end{tabular}


Table 3 continued

\begin{tabular}{|c|c|c|c|c|}
\hline & $\begin{array}{l}\text { Licensing and spin-outs: } \\
\text { Teaching led institutions }\end{array}$ & $\begin{array}{l}\text { Licensing and spin-outs: } \\
\text { Research-intensive } \\
\text { institutions }\end{array}$ & $\begin{array}{l}\text { Problem-solving: } \\
\text { Teaching led } \\
\text { institutions }\end{array}$ & $\begin{array}{l}\text { Problem-solving: } \\
\text { Research-intensive } \\
\text { institutions }\end{array}$ \\
\hline \multirow[t]{2}{*}{$\begin{array}{l}\text { Previously employee of a public } \\
\text { organisation }\end{array}$} & $-0.006^{*}$ & $-0.018 * * *$ & $0.047 * * *$ & 0.009 \\
\hline & $(0.003)$ & $(0.004)$ & $(0.011)$ & $(0.012)$ \\
\hline Previously employee of a charity & $\begin{array}{r}-0.001 \\
(0.004)\end{array}$ & $\begin{array}{c}0.005 \\
(0.006)\end{array}$ & $\begin{array}{l}0.037 * * * \\
(0.013)\end{array}$ & $\begin{array}{l}0.086^{* * * *} \\
(0.015)\end{array}$ \\
\hline \multicolumn{5}{|l|}{ Control variables } \\
\hline Degree of centralisation & $\begin{array}{c}0.018 \\
(0.021)\end{array}$ & $\begin{array}{c}0.058 \\
(0.111)\end{array}$ & $\begin{array}{l}-0.527 * * * \\
(0.072)\end{array}$ & $\begin{array}{l}0.591 * \\
(0.332)\end{array}$ \\
\hline Index of specialisation & $\begin{array}{r}0.002 \\
(0.010)\end{array}$ & $\begin{array}{r}-0.005 \\
(0.029)\end{array}$ & $\begin{array}{c}0.019 \\
(0.032)\end{array}$ & $\begin{array}{c}-0.628 * * * \\
(0.084)\end{array}$ \\
\hline Proportion of women & $\begin{array}{r}-0.014 \\
(0.022)\end{array}$ & $\begin{array}{r}-0.038 \\
(0.050)\end{array}$ & $\begin{array}{l}-0.159 * * \\
(0.073)\end{array}$ & $\begin{array}{r}-0.047 \\
(0.152)\end{array}$ \\
\hline \multirow[t]{2}{*}{$\begin{array}{l}\text { Proportion of employees younger } \\
\text { than } 40\end{array}$} & $0.041 *$ & 0.038 & $0.229 * * *$ & -0.114 \\
\hline & $(0.025)$ & $(0.053)$ & $(0.079)$ & $(0.167)$ \\
\hline \multirow{2}{*}{$\begin{array}{l}\text { Gender of respondent } \\
\quad(\text { female }=1)\end{array}$} & $-0.021 * * *$ & $-0.013 * * *$ & $-0.081 * * *$ & $-0.051 * * *$ \\
\hline & $(0.003)$ & $(0.004)$ & $(0.011)$ & $(0.011)$ \\
\hline Observations & 10,868 & 9988 & 10,868 & 9988 \\
\hline
\end{tabular}

Probit models for entrepreneurial activities at the national level, reporting marginal effects. Standard errors are in parentheses. Discipline dummies are also included (coefficients not shown). * Significant at $10 \%$ level, ** significant at $5 \%$ level, *** significant at $1 \%$ level

academics in either type of university. Finally, prior work experience particularly within SMEs plays an important role in driving both types of entrepreneurial engagements at both types of institutions. We find that a broader range of prior employment experiences spanning large firms, public organisations and charity organisations, to be beneficial involvement in problem-solving activities. This is in line with the literature, which suggests that having an understanding of the different cultural settings of universities and businesses can help to overcome an important barrier for the entrepreneurial engagements of universities (Mina and Probert 2012).

\subsection{Blinder-Oaxaca decomposition}

We now turn to a more detailed analysis of the geography of entrepreneurial activities. This is of significant policy relevance, as much of the policy discourse focuses on the impact of universities on national or regional competitiveness, with the local dimension often overlooked. As discussed in Sect. 4.2, we use a Blinder-Oaxaca decomposition approach to analyse whether the difference in outcomes is due to a difference in the endowments (i.e., the observed characteristics within different institutions), or in the coefficients (i.e., the unobserved/ unmeasured behavioural responses to those characteristics). The results of the Blinder-Oaxaca decomposition for problem-solving activities are shown in Table $4 .^{8}$

As demonstrated by the aggregate decomposition analysis in Table 4, there are significant differences in the geography of entrepreneurial engagement between the two types of universities, supporting the prepositions of Hypothesis 4. We find that research-intensive universities are more likely to engage with national and international entrepreneurial opportunities while

\footnotetext{
${ }^{8}$ Due to the nature of the question on licensing and spinouts in the UK-HEI survey, which focused on the frequency of these outcomes, we are unable to analyse the geography of more formal commercialisation activities.
} 
Table 4 Oaxaca decomposition for academic engagement in problem-solving activities, at different geographies

\begin{tabular}{|c|c|c|c|c|}
\hline & $\begin{array}{l}\text { Local } \\
\text { (Group1: teaching-led) }\end{array}$ & $\begin{array}{l}\text { Regional } \\
\text { (Group1: teaching-led) }\end{array}$ & $\begin{array}{l}\text { National } \\
\text { (Group1: research int) }\end{array}$ & $\begin{array}{l}\text { International } \\
\text { (Group1: research int) }\end{array}$ \\
\hline Difference & $\begin{array}{l}0.031 * * * \\
(4.83)\end{array}$ & $\begin{array}{l}0.089 * * * \\
(13.29)\end{array}$ & $\begin{array}{l}0.044 * * * \\
(6.31)\end{array}$ & $\begin{array}{l}0.112 * * * \\
(16.35)\end{array}$ \\
\hline Endowments & $\begin{array}{r}-0.009 \\
(0.40)\end{array}$ & $\begin{array}{l}0.051 * * \\
(2.08)\end{array}$ & $\begin{array}{l}0.052 * * * \\
(6.24)\end{array}$ & $\begin{array}{l}0.091 * * * \\
(10.84)\end{array}$ \\
\hline Coefficients & $\begin{array}{l}-0.057 * * * \\
(6.32)\end{array}$ & $\begin{array}{l}0.030 * * * \\
(3.00)\end{array}$ & $\begin{array}{l}0.078 * * * \\
(3.27)\end{array}$ & $\begin{array}{c}-0.014 \\
(0.57)\end{array}$ \\
\hline Interaction & $\begin{array}{l}0.097 * * * \\
(4.32)\end{array}$ & $\begin{array}{r}0.007 \\
(0.28)\end{array}$ & $\begin{array}{l}-0.087 * * * \\
(3.55)\end{array}$ & $\begin{array}{c}0.034 \\
(1.39)\end{array}$ \\
\hline
\end{tabular}

In the first two columns, the reference group (Group 1) is teaching-led universities. In the last two columns, the reference group is research-intensive universities

Oaxaca decomposition into endowments, coefficients and interaction terms. Standard errors are in parentheses. Problem-solving activities include: joint research, contract research, research consortia, consultancy, informal advice, and joint publications. $* * *$ Significant at $1 \%$ level, $* *$ significant at $5 \%$ level, $*$ significant at $10 \%$ level

teaching-led universities engage with the local and regional opportunities. When we examine the sources of this specialisation using the Blinder-Oaxaca decomposition, the first result to note is that differences in the coefficients (i.e. in the behavioural responses) dominate at low levels of geography, while differences in the endowments are more relevant at greater geographies. In particular, the differences in international engagement between the two types of universities are mostly due to differences in the institutional characteristics of the two types of universities and their staff. Conversely, the differences in local engagement between the two types of universities mostly result from the "coefficients" effect, suggesting that there are behavioural reasons behind the different levels of local engagement. In other words, if academics in research-intensive universities were able to emulate the behavioural responses of academics in teaching-led universities (for instance, if they were to adopt similar routines and a similar culture regarding IP enforcements for inventions; see Table A1 in the Digital Appendix), then they could possibly close the gap with teachingled institutions in terms of local entrepreneurial activities and play a more significant role in their local economies. Given that policies emphasising national and international excellence, instead of local engagement, dominate the symbolic elements of the UK higher education sector, the low levels of local engagement by the research-intensive universities are not surprising. Similarly, if academics in teaching-led institutions could change the configuration of their institutional endowments (e.g. if they employed more staff undertaking basic research) they might be able to close the gap at the international level. These findings have important implications particularly for policy makers who consider understanding the determinants of the geographical reach of entrepreneurial engagement.

\section{Discussion}

As highlighted by Audretsch (2014), the role of the university in the entrepreneurial society goes beyond patenting, licensing and start-up generation, and extends to broader activities that promote entrepreneurial thinking, values, institutions, and what is referred to as "entrepreneurship capital". Following this argument and responding to the calls for a better understanding of the multitude of institutional forms in entrepreneurial universities (Van Looy et al. 2011), we argue that the phenomenon of the entrepreneurial university is a heterogeneous concept and can no longer be limited to the context of research-intensive institutions only. This is also supported by the growing case study evidence on the less research-intensive universities becoming increasingly important and proactive facilitators of innovation and entrepreneurship, especially at a regional level (Calzonetti et al. 2012; Braunerhjelm and Helgesson 2006). 
Hence, in this paper, we explicitly extend the analysis of entrepreneurial activities to both researchintensive and teaching-led universities. Drawing on the insights from institutional theory and based on the analysis of a unique large-scale survey of academics in all disciplines across all higher education institutions in the UK, we provide a robust comparative picture of the scale, nature and determinants of entrepreneurial activities in both types of institutions. Our results are generally supportive of the hypotheses, formulated (in Sect. 3.1) along the regulative, normative and cognitive pillars of academic institutions. For instance, we find that university regulations only have a relatively limited effect on entrepreneurial activities of academics. This strongly resonates with the ongoing institutional theory debate about regulations often being too complex and controversial to give clear directions for conduct, making individual actors increasingly rely on normative and cognitive interpretations of the rules (Thornton et al. 2013; Creed et al. 2014).

We find that it is the normative and, especially, cognitive influences which are underlying the patterns of entrepreneurial activities in both types of institutions. While previous research notes that academic entrepreneurship occurs at the boundaries of different academic and professional profiles (Wright et al. 2007; Urbano and Guerrero 2013), much of this literature does not attend to the complexities associated with combining such scientific and managerial logics. Our results indicate that the university's emphasis on blending academic and managerial roles performs as an important signal for those individuals who are engaged in problem-solving activities in teaching-led universities, and licensing and spin-out activities in research-led universities. Thus, academics, who develop a variety of competencies in various institutional spheres, tend to display dispositions towards investing in certain institutional arrangements, which may be reflective of a relative competitive advantage of a given institution. This aligns with the arguments of Voronov and Yorks (2015), who have highlighted the nature of such institutional arrangements being imprinted in individual and institutional logics, and internalised in the form of durable dispositions.

Similarly, prior university and business experience of academics provides them with cognitive guidance when it comes to entrepreneurial activities. Such cognitive guidance, and a person's engagement with a variety of activities in different task domains, condition their knowledge and actions. The experience of academics from previous institutional work is filtered and reflected on new institutional work, such as entrepreneurial activities, suggesting that cognitive frameworks shape entrepreneurial norms (Yousafzai et al. 2015). In particular, our findings suggest that involvement in problem-solving activities benefits from the presence of academics with a broad range of experience and from different backgrounds, whilst involvement in licensing and spin-out activities benefits from the existence of a narrower range of prior experience. This suggests that the nature of formal entrepreneurial activities such as licensing and spinouts entails more specific cultural capital and entrepreneurial know-how, whereas problem-solving activities require a generalised awareness of cognitive and normative submersion. This is linked to the "embedded agency" debate in institutional theory, whereby the emphasis is on how individuals express agency through development of certain cognitive and normative capacity in order to realise particular institutional arrangements rather than raising institutional conditions and possibilities into fuller consciousness and realm of institutional work (Seo and Creed 2002; Nilsson 2015).

One of the key hypotheses of our study is related to the geographical specialisation of the entrepreneurship activities of research-intensive and teaching-led universities. Underpinned by the institutional theory perspective, we investigate the effects of structures and actions on the geographical patterns of entrepreneurial activities in the two types of universities. Through our decomposition analysis we reveal that differences in behavioural responses (or actions) dominate problem-solving activities at low levels of geography (i.e. local), where teaching-led universities are more active. Conversely, it is endowments (or structures) that matter more at greater geographies (i.e. international), dominated by research-intensive universities. Following the institutional logics perspective, these findings indicate that when it comes to making an impact on a local scale, university managers need to pay more attention to "symbolic" elements of institutions (such as meanings attached to the university structures and practices), whereas at a greater geographical scale the impact can be achieved through putting in place the "right" composition of resources. Symbolic dimensions of institutional work signal such behavioural forms that structures the local 
field accordingly. Impact of entrepreneurial activities, at a greater geographical scale, is contingent upon reconfiguration of resources and repetitive practices.

\section{Conclusions}

Based on the proposition that entrepreneurship scholars need to cover a broader range of institutional contexts (types of universities) and institutional arrangements (types of entrepreneurial activities) in order to realise the full potential of research in the domain of the entrepreneurial university, in this paper we make a contribution along three distinct dimensions.

First, we advance the existing literature by bringing on the "research radar" entrepreneurial activities undertaken by teaching-led universities. The entrepreneurial engagements of academics in teaching-led universities are normally neglected by the literature, but shown here to be diverse and of comparable magnitude to those by research-led institutions. Teaching-led universities are an integral part of innovation and entrepreneurship systems, and characterised by strong entrepreneurial cultures embedded in multi-dimensional entrepreneurial practices of their academics. Effectively, many types of entrepreneurial activities are dominated by teaching-led universities, with particularly high rates of participation occurring at the regional and local levels.

Second, we embed our analysis within the institutional theory discourse, which is increasingly used in qualitative studies on entrepreneurship but often proves challenging to operationalise in large-scale quantitative empirical studies due to limited data availability. We specifically address the calls of institutional theory scholars to provide more evidence on the interplay between the micro-individual and meso-structural dynamics in institutional theory. The application of institutional theory (to such large-scale quantitative data) allows for multi-level measures and analysis techniques that help entrepreneurship research to interactively address complex social phenomena such as the entrepreneurial university.

Third, from a policy perspective our results suggest that innovation and entrepreneurship policy in the UK should pay more attention to the competitive strengths of teaching-led institutions when designing recommendations on cross-institutional collaboration to promote economic growth. This policy recommendation also carries importance beyond the UK, particularly considering the changing funding landscape across Europe and the shift in the emphasis towards further "third mission" activities. Teachingled universities can be better integrated into national entrepreneurial eco-systems, provided with more support to engage with public, private and nongovernmental organisations, and given more access to resources relevant to the kind of institutional activities they pursue. This should be aligned with university-level leadership and decision-making processes attuned with such processes of change, institutional adaptation and enhancement. The policy debate has only recently started to acknowledge that university-business partnerships should be aimed not only at technology transfer and research-intensive activities, but also at employability solutions and entrepreneurial options embedded within university teaching activities (Drager 2016), with our research providing strong empirical support for the latter two aspects.

While focusing on entrepreneurial activities rather than their economic outcomes, we identify a few further avenues for exploring the entrepreneurial university. The most immediate extension of our research would be a comparative analysis of the extent to which the entrepreneurial activities of academics in the two types of the universities translate into economic and social development at different geographical scales. Another fruitful research direction would be to advance the multi-level insights generated through institutional theory by undertaking an in-depth qualitative and systematic research into selected universities across different national and institutional contexts. We argue that continued analysis of entrepreneurial activities in diverse institutional settings will advance our understanding of institutional reproduction and/or change in entrepreneurial universities.

Open Access This article is distributed under the terms of the Creative Commons Attribution 4.0 International License (http:// creativecommons.org/licenses/by/4.0/), which permits unrestricted use, distribution, and reproduction in any medium, provided you give appropriate credit to the original author(s) and the source, provide a link to the Creative Commons license, and indicate if changes were made.

\section{Appendix}

See Table 5 . 
Table 5 Description of the variables included in the analysis. All are dummy variables unless otherwise specified

Variable Data source Description

Dependent variables

Licensing and spin-outs

UK HEI

Problem-solving

UK HEI

(2009)

\section{Regulative dimension}

IP for inventions

IP for arts/literature

TTO department

Normative dimension

Importance of engagement

Average use of TTO

Proportion managers

\section{Cognitive dimension}

Professor, Associate Professor, Lecturer, Research Fellow

Basic research

Use-inspired research

Applied research

Age

Business experience

\section{Control variables}

Index of specialisation

Degree of centralisation

Proportion of women

Proportion of $<40$ years

Proportion business experience

Health sciences, biological sciences, engineering and physical sciences, social sciences, business and media, humanities, creative arts, education

Whether the respondent has licensed a research output or founded a spin-out company based on their research.

Whether the responded has engaged in problem-solving activities with non-academic partners, including: joint research, contract research, research consortia, consultancy, informal advice, joint publications.

UK HEI

HE-BCI

Survey

HE-BCI

Survey

(2007)

UK HEI

UK HEI

UK HEI

UK HEI (2009)

RHEI (2006-07)

RHEI

(2006-07)

UK HEI

(2009)

UK HEI

(2009)
Proportion of academics who think that work with business and industry is considered "very important" in their institution with regards to career advancement and promotion.

Proportion of academics who have used the TTO occasionally or frequently in the past three years.

Academic staff who have management responsibilities.

Whether the respondent is a professor, Associate Professor, Lecturer, Research Fellow (reference category $=$ other).

Type of research carried out by the respondent (Stokes 1997). Basic research is defined as research that has no direct application; use-inspired research is basic research that is inspired by considerations of use; and applied research is that which is directed towards an individual, group or societal need or use.

Age group of the respondent ((30-39)-(40-49)- $(\geq 50)$ (note that $<30$ is the reference category).

Whether the respondent has experience of starting a SME or being employed in a SME, large business, public organisation or charity.

Simpson index measuring the probability that two individuals chosen at random from the same institution belong to the same discipline.

Proportion of staff in central administration as a function of total university staff (both FTE).

Proportion of women; academic staff aged below 40 years; academic staff who have experience of starting or running a small business.

Academic discipline. Note that disciplines are included in all of the regressions, but the coefficients are not shown. Please refer to the digital appendix for the full results including those for the disciplines. 


\section{References}

Abramovsky, L., Harrison, R., \& Simpson, H. (2007). University research and the location of business R\&D. Economic Journal, 117(519), 114-141.

Abreu, M., \& Grinevich, V. (2013). The nature of academic entrepreneurship in the UK: Widening the focus on entrepreneurial activities. Research Policy, 42(2), 408-422.

Abreu, M., Grinevich, V., Hughes, A., \& Kitson, M. (2009). Knowledge exchange between academics and the business, public and third sectors. Cambridge: UK Innovation Research Centre, University of Cambridge and Imperial College London.

Acosta, M., \& Coronado, D. (2003). Science-technology flows in Spanish regions: An analysis of scientific citations in patents. Research Policy, 32(10), 783-803.

Acs, Z. J., Braunerhjelm, P., Audretsch, D., \& Carlsson, B. (2009). The knowledge spillover theory of entrepreneurship. Small Business Economics, 32(1), 15-30.

Acs, Z. J., Autio, E., \& Szerb, L. (2014). National systems of entrepreneurship: Measurement issues and policy implications. Research Policy, 43(3), 476-494.

Agrawal, A., \& Henderson, R. (2002). Putting patents in context: Exploring knowledge transfer from MIT. Management Science, 48(1), 44-60.

Ahlstrom, D., \& Bruton, G. D. (2002). An institutional perspective on the role of culture in shaping strategic actions by technology-focused entrepreneurial firms in China. Entrepreneurship Theory and Practice, 26(4), 53-70.

Allen, S. D., Link, A. N., \& Rosenbaum, D. T. (2007). Entrepreneurship and Human Capital: Evidence of Patenting Activity from the Academic Sector. Entrepreneurship Theory and Practice, 31(6), 937-951.

Audretsch, D. (2014). From the entrepreneurial university to the university for the entrepreneurial society. Journal of Technology Transfer, 39(3), 313-321.

Audretsch, D., Hulsbeck, M., \& Lehmann, E. (2012). Regional competitiveness, university spillovers, and entrepreneurial activity. Small Business Economics, 39(3), 587-601.

Audretsch, D., \& Keilbach, M. (2009). Resolving the knowledge paradox: Knowledge-spillover entrepreneurship and economic growth. Research Policy, 37(10), 1697-1705.

Audretsch, D. B., \& Lehmann, E. (2006). What determines the variation in entrepreneurial success? In Proceedings: Community affairs dept. conferences (No. Jul, pp. 165-189). Federal Reserve Bank of Kansas City.

Azoulay, P., Ding, W., \& Stuart, T. (2007). The determinants of faculty patenting behavior: Demographics or opportunities? Journal of Economic Behavior \& Organization, 63(4), 599-623.

Bania, N., Eberts, R., \& Fogarty, M. (1993). Universities and the startups of new companies: Can we generalise from Route 128 and Silicon Valley? The Review of Economics and Statistics, 75(4), 761-766.

Beeson, P., \& Montgomery, E. (1993). The effects of colleges and universities on local labour markets'. Review of Economics and Statistics, 75(4), 753-761.

Bercovitz, J., Feldman, M., Feller, I., \& Burton, R. (2001). Organizational structure as a determinant of academic patent and licensing behavior: An exploratory study of
Duke, Johns Hopkins, and Pennsylvania State universities. Journal of Technology Transfer, 26(1-2), 21-35.

Black, J., Boggs, A. M., Fry, H., Hillman, N., Jackson, S., King, R., et al. (2015). The regulation of higher education. Discussion Paper 77, Centre for Analysis of Risk and Regulation, School of Economics and Political Science, London.

Blinder, A. S. (1973). Wage discrimination: Reduced form and structural estimates. Journal of Human Resources, 7(3), 436-455.

Block, J. H., Kohn, K., Miller, D., \& Ullrich, K. (2015). Necessity entrepreneurship and competitive strategy. Small Business Economics, 44(1), 37-54.

Bonaccorsi, A., Colombo, M. G., Guerini, M., \& Rossi-Lamastra, C. (2014). The impact of local and external university on the creation of knowledge-intensive firms: Evidence from the Italian case. Small Business Economics, 43(2), 261-287.

Boucher, G., Conway, C., \& Van Der Meer, E. (2003). Tiers of engagement by universities in their region's development. Regional Studies, 37(9), 887-897.

Bourdieu, P. (1974). The specificity of the scientific field and the social conditions of the progress of reason. Social Science Information, 6, 10-35.

Braunerhjelm, P., \& Helgesson, C. (2006). The emergence of a European biotechnology cluster: The case of Medicon Valley. In P. Braunerhjelm \& M. Feldman (Eds.), Cluster genesis: The origins and emergence of technology-based economic development. Oxford: Oxford University Press.

Bronstein, J., \& Reihlen, M. (2014). Entrepreneurial university archetypes: A meta-synthesis of case study literature. Industry and Higher Education, 28(4), 245-262.

Bruton, G. D., Fried, V. H., \& Manigart, S. (2005). Institutional influences on the worldwide expansion of venture capital. Entrepreneurship Theory and Practice, 29(6), 737-760.

Busenitz, L. W., Gomez, C., \& Spencer, J. W. (2000). Country institutional profiles: Unlocking entrepreneurial phenomena. Academy of Management Journal, 43(5), 994-1003.

Calzonetti, F. J., Miller, D. M., \& Reid, N. (2012). Building both technology-intensive and technology-limited clusters by emerging research universities: The Toledo example. Applied Geography, 34(2012), 265-273.

Chapple, W., Lockett, A., Siegel, D., \& Wright, M. (2005). Assessing the relative performance of UK university technology transfer offices: Parametric and non-parametric evidence. Research Policy, 34(3), 369-384.

Clark, B. R. (1998). Creating entrepreneurial universities. Paris $\&$ Oxford: IAU and Elsevier Science.

Clark, K., \& Drinkwater, S. (2010). Patterns of ethnic self-employment in time and space: Evidence from British Census Microdata. Small Business Economics, 34(3), 323-338.

Cochrane, A., \& Williams, R. (2013). Putting higher education in its place: The socio-political geographies of English universities. Policy and Politics, 41(1), 43-58.

Creed, W. E. D., Hudson, B. A., Okhuysen, G. A., \& SmithCrowe, K. (2014). Swimming in a sea of shame: Incorporating emotion into explanations of institutional reproduction and change. Academy of Management Review, 39, 275-301.

D'Este, P., \& Iammarino, S. (2010). The spatial profile of university-business research partnerships. Papers in Regional Science, 89(2), 335-350. 
D'Este, P., \& Patel, P. (2007). University-industry linkages in the UK: What are the factors underlying the variety of interactions with industry. Research Policy, 36(9), 1295-1313.

D’Este, P., \& Perkmann, M. (2011). Why do academics engage with industry? The entrepreneurial university and individual motivations. The Journal of Technology Transfer, 36, 316-339.

Di Gregorio, D., \& Shane, S. (2003). Why do some universities generate more start-ups than others? Research Policy, 32(2), 209-227.

Dietz, J. S., \& Bozeman, B. (2005). Academic careers, patents, and productivity: Industry experience as scientific and technical human capital. Research Policy, 34(3), 349-367.

Ding, W., \& Choi, E. (2001). Divergent paths to commercial science: A comparison of scientists' founding and advising activities. Research Policy, 40(1), 69-80.

Ding, W. W., Murray, F., \& Stuart, T. E. (2006). Gender differences in patenting in the academic life sciences. Science, 313(5787), 665-667.

Drager, J. (2016). Dealing with realities: How university-business partnerships help solving higher-education's challenges. Presentation at the University-Business Forum, Vienna, 25-26 February.

Etzkowitz, H. (2003). Research groups as 'quasi-firms': The invention of the entrepreneurial university. Research Policy, 32, 109-121.

Fairlie, R. W. (1999). The absence of the African-American owned business: An analysis of the dynamics of selfemployment. Journal of Labor Economics, 17(1), 80-108.

Foss, L., \& Gibson, D. V. (Eds.). (2015). The entrepreneurial university: Context and institutional change. Abingdon: Routledge.

Gilman, M., \& Serbanica, C. (2015). University-industry linkages in the UK: Emerging themes and 'unanswered'questions. Prometheus, 32(4), 1-37.

Grimaldi, R., \& Grandi, A. (2005). Business incubators and new venture creation: An assessment of incubating models. Technovation, 25(2), 111-121.

Guerrero, M., \& Urbano, D. (2014). Academics' start-up intentions and knowledge filters: An individual perspective of the knowledge spillover theory of entrepreneurship. Small Business Economics, 43(1), 57-74.

Guerrero, M., Urbano, D., \& Fayolle, A. (2014). Entrepreneurial activity and regional competitiveness: evidence from European entrepreneurial university. Journal of Technology Transfer, 41(1), 105-131.

Hagstrom, W. (1966). The scientific community. New York: Basic Books.

He, L. (2008). Do founders matter? A study of executive compensation, governance structure and firm performance. Journal of Business Venturing, 23(3), 257-279.

Higher Education Green Paper. (2015). Fulfilling our potential: Teaching excellence, social mobility and student choice. Department for Business, Innovation and Skills, United Kingdom. https://bisgovuk.citizenspace.com/he/fulfillingourpotential/supporting_documents/Fulfilling $\% 20$ our $\%$ 20Potential $\% 20 \% 20$ Teaching $\% 20$ Excellence $\% 20$ Social $\%$ 20Mobility\%20and\%20Student $\% 20$ Choice.pdf.

Howells, J. R. L., Karataş-Özkan, M., Yavuz, C., \& Atiq, M. (2014). University management and organisational change: A dynamic institutional perspective. Cambridge Journal of Regions, Economy and Society, 7, 251-270.

Hwang, H., \& Powell, W. W. (2005). Institutions and entrepreneurship. In S. A. Alvarez, R. Agarwal, \& O. Sorenson (Eds.), Handbook of entrepreneurship research: Disciplinary perspectives (pp. 179-210). New York: Springer.

Jacob, M., Lundqvist, M., \& Hellsmark, H. (2003). Entrepreneurial transformations in the Swedish university system: The case of Chalmers University of Technology. Research Policy, 32(9), 1555-1569.

Jann, B. (2008). A Stata implementation of the Blinder-Oaxaca decomposition. Stata Journal, 8(4), 453-479.

Karataş-Özkan, M. (2011). Understanding relational qualities of entrepreneurial learning: Towards a multi-layered approach. Entrepreneurship \& Regional Development, 23(9-10), 877-906.

Karataş-Özkan, M., \& Chell, E. (2015). Gender inequalities in academic innovation and enterprise: A Bourdieuian analysis. British Journal of Management, 26(1), 109-125.

Karataş-Özkan, M., Anderson, A. R., Fayolle, A., Howells, J., \& Condor, R. (2014). Understanding entrepreneurship: Challenging dominant perspectives and theorising entrepreneurship through new post positivist epistemologies. Journal of Small Business Management, 52(4), 589-593.

Kirby, D. A. (2005). Creating entrepreneurial universities in the UK: Applying entrepreneurship theory to practice. Journal of Technology Transfer, 31(5), 599-603.

Kirby, D., Guerrero, M., \& Urbano, D. (2011). Making universities more entrepreneurial: Development of a model. Canadian Journal of Administrative Sciences, 28(3), 302-316.

Klapper, R., \& Refai, D. (2015). A Gestalt model of entrepreneurial learning. In D. Rae \& C. Wang (Eds.), Entrepreneurial Learning: New Perspectives in Research (pp. 156-177). London: Education and Practice, Routledge.

Klofsten, M., \& Jones-Evans, D. (2000). Comparing academic entrepreneurship in Europe-The case of Sweden and Ireland. Small Business Economics, 14(4), 299-310.

Krueger, N. F., Reilly, M. D., \& Carsurd, A. L. (2000). Competing models of entrepreneurial intentions. Journal of Business Venturing, 15(5), 411-432.

Lebeau, Y., \& Cochrane, A. (2015). Rethinking the 'third mission': UK universities and regional engagement in challenging times. European Journal of Higher Education, $5(3), 250-263$.

Lester (2005). Universities, innovation, and the competitiveness of local economies. In A summary report from the Local Innovation Systems Project-Phase 1. MIT Industrial Performance Centre Working paper 05-010.

Lockett, A., Siegel, D., Wright, M., \& Ensley, M. D. (2005). The creation of spin-off firms at public research institutions: Managerial and policy implications. Research Policy, 34(7), 981-993.

Lofstrom, M., \& Bates, T. (2009). Latina entrepreneurship. Small Business Economics, 33(4), 427-439.

Lofsten, H., \& Lindelof, P. (2005). R\&D networks and product innovation patterns-Academic and non-academic new technology-based firms on science parks. Technovation, 25(9), 1025-1037. 
Louis, K. S., Blumenthal, D., Gluck, M. E., \& Stoto, M. A. (1989). Entrepreneurs in academe: An exploration of behaviors among life scientists. Administrative Science Quarterly, 34(1), 110-131.

Lounsbury, M., \& Beckman, C. M. (2015). Celebrating organization theory. Journal of Management Studies, 52(2), 288-308.

Manolova, T., Eunni, R., \& Gyoshev, B. (2008). Institutional environments for entrepreneurship: Evidence from emerging economies in Eastern Europe. Entrepreneurship Theory \& Practice, 32(1), 203-218.

Markman, F. D., Phan, P. H., Balkin, D. B., \& Gianiodis, P. T. (2005). Entrepreneurship and university-based technology transfer. Journal of Business Venturing, 20(2), 241-263.

Mars, M. M., \& Rios-Aguilar, C. (2010). Academic entrepreneurship (re)defined: Significance and implications for the scholarship of higher education. Higher Education, 59(4), 441-460.

Mian, S. A. (2011). University's involvement in technology business incubation: What theory and practice tell us? International Journal of Entrepreneurship and Innovation Management, 13(2), 113-121.

Mina, A. \& Probert, J. (2012) Enhancing collaboration creating value-Business interaction with the UK research base in four sectors, CIHE-UK-IRC enhancing value task force, September.

Moisander, J. K., Hirsto, H. \& Fahy, K. M. (2016). Emotions in institutional work: a discursive perspective. Organization Studies, 37(7), 1-28. doi:10.1177/0170840615613377.

Mosey, S., \& Wright, M. (2007). From human capital to social capital: A longitudinal study of technology-based academic entrepreneurs. Entrepreneurship Theory \& Practice, 31(6), 909-935.

Mueller, P. (2006). Exploring the knowledge filter: How entrepreneurship and university-industry relationships drive economic growth. Research Policy, 35(10), 1499-1508.

Mueller, P. (2007). Exploiting entrepreneurial opportunities: The impact of entrepreneurship on growth. Small Business Economics, 28(4), 355-362.

Nilsson, W. (2015). Positive institutional work: Exploring institutional work through the lens of positive organisational scholarship. Academy of Management Review, 40, 370-398.

Nomaler, O., \& Verspagen, B. (2008). Knowledge flows, patent citations and the impact of science and technology. Economic Systems Research, 20(4), 339-366.

North, D. C. (1990). Institutions, institutional change and economic performance. Cambridge: University Press.

North, D. C. (2005). Understanding the process of economic change. Princeton, NJ: Princeton University Press.

O'Shea, R., Allen, T. J., Chevalier, A., \& Roche, F. (2005). Entrepreneurial orientation, technology transfer and spinoff performance of US universities. Research Policy, 34(7), 994-1009.

O'Shea, R. P., Allen, T. J., Morse, K. P., O'Gorman, C., \& Roche, F. (2007). Delineating the anatomy of an entrepreneurial university: The Massachusetts Institute of Technology experience. $R \& D$ Management, 37(1), 1-16.

Oaxaca, R. (1973). Male-female wage differentials in urban labor markets. International Economic Review, 14(3), 693-709.
Perkmann, M., Tartari, V., McKelvey, M., Autio, E., Broström, A., D'Este, P., et al. (2013). Academic engagement and commercialisation: A review of the literature on university-industry relations. Research Policy, 42(2), 423-442.

Witty Review. (2013). Encouraging a British invention revolution: Sir Andrew Witty's Review of universities and growth: Final report and recommendations. Department for Business, Innovation and Skills.

Rothaermel, F. T., Agung, S. D., \& Jiang, L. (2007). University entrepreneurship: A taxonomy of the literature. Industrial and Corporate Change, 16(4), 691-791.

Russell Group (2015). Profile, https://www.russellgroup.ac.uk/ media/4997/profile-of-the-russell-group-of-universities.pdf

Scott, W. R. (1995). Institutions and organizations. Thousand Oaks, CA: Sage.

Scott, W. R. (2005). Institutional theory. In G. Ritzer (Ed.), Encyclopedia of social theory (Vol. 1, pp. 408-414). Thousand Oaks, CA: Sage.

Scott, W. R. (2014). Institutions and organizations: Ideas, interests and identity. Thousand Oaks, CA: Sage Publications.

Scott, W. R., \& Meyer, J. W. (1991). The organization of societal sectors: Propositions and early evidence. In W. W. Powell \& P. J. DiMaggio (Eds.), New institutionalism in organizational analysis (pp. 108-140). Chicago: University of Chicago Press.

Seo, M. G., \& Creed, W. E. D. (2002). Institutional contradictions, praxis and institutional change: A dialectical perspective. Academy of Management Review, 27, 222-247.

Shane, S. (2004). Academic entrepreneurship: University spinoffs and wealth creation. UK/Northampton, MA, USA: Edward Elgar Cheltenham.

Siegel, D. S., Waldman, D. A., Atwater, L. E., \& Link, A. N. (2004). Toward a model of the effective transfer of scientific knowledge from academicians to practitioners: Qualitative evidence from the commercialization of university technologies. Journal of Engineering and Technology Management, 21(1), 115-142.

Siegel, D., Westhead, P., \& Wright, M. (2003). Science parks and the performance of new technology-based firms: A review of recent U.K. evidence and an agenda for future research. Small Business Economics, 20(2), 177-184.

Siegel, D., Wright, M., Chapple, W., \& Lockett, A. (2008). Assessing the relative performance of university technology transfer in the US and UK: A stochastic distance function approach. Economics of Innovation and New Technology, 17(7-8), 717-729.

Stokes, D. E. (1997). Pasteur's quadrant: Basic science and technological innovation. Brookings: Washington D.C.

Thompson, P., \& Fox-Kean, M. (2005). Patent citations and the geography of knowledge spillovers: A Reassessment. American Economic Review, 95(1), 450-460.

Thompson, M., \& Willmott, H. (2016). The social potency of affect: Identification and power in the immanent structuring of practice. Human Relations, 69(2), 483-506.

Thornton, P. H., Ocasio, W., \& Lounsbury, M. (2013). The institutional logics perspective: A new approach to culture, structure, and process. Oxford: Oxford University Press.

Thursby, J. G., Jensen, R. A., \& Thursby, M. C. (2001). Objectives, characteristics and outcomes of university licensing: A survey of major U.S. universities. Journal of Technology Transfer, 26(1-2), 59-70. 
Tiffin, S., \& Kunc, M. (2011). Measuring the roles universities play in regional innovation systems: A comparative study between Chilean and Canadian natural resource-based regions. Science and Public Policy, 38(1), 55-66.

Tolbert, P. S., David, R. J., \& Sine, W. D. (2011). Studying choice and change: The intersection of institutional theory and entrepreneurship research. Organization Science, 22(5), 1332-1344.

Urbano, D., \& Guerrero, M. (2013). Entrepreneurial universities: Socio-economic impacts of academic entrepreneurship in a European region. Economic Development Quarterly, 27(1), 40-55.

Van Looy, B., Debackere, K., \& Andries, P. (2003). Policies to stimulate regional innovation capabilities via universityindustry collaboration: An analysis and an assessment. R\&D Management, 33, 209-229.

Van Looy, B., Landoni, P., Callaert, J., Van Pottelsberghe, B., Sapsalis, E., \& Debackere, K. (2011). Entrepreneurial effectiveness of European universities: An empirical assessment of antecedents and trade-offs. Research Policy, 40(4), 533-564.

van Rijnsover, F. J., Hessels, L., \& Vadeberg, R. L. J. (2008). A resource-based view on the interaction of university researchers. Research Policy, 37(8), 1255-1266.

Veciana, J. M., \& Urbano, D. (2008). The institutional approach to entrepreneurship research: An introduction. International Entrepreneurship and Management Journal, 4(4), 365-379.
Voronov, M., \& Vince, R. (2012). Integrating emotions into analysis of institutional work. Academy of Management Review, 37, 58-81.

Voronov, M., \& Yorks, L. (2015). “Did you notice that?' Theorizing differences in the capacity to apprehend institutional contradictions. Academy of Management Review, 40, 563-586.

Wagner, J. (2008). A note on why more West than East German firms export. International Economics and Economic Policy, 5(4), 363-370.

Wright, M., Clarysse, B., Mustar, P., \& Lockett, A. (2007). Academic entrepreneurship in Europe. Cheltenham: Edward Elgar.

Yamakawa, Y., Peng, M. W., \& Deeds, D. L. (2008). What drives new ventures to internationalise from emerging to developed economies'. Entrepreneurship Theory and Practice, 32(1), 59-82.

Yousafzai, S., Saeed, S., \& Muffatto, M. (2015). Institutional theory and contextual embeddedness of women's entrepreneurial leadership: Evidence from 92 countries. Journal of Small Business Management, 53(3), 587-604.

Zucker, L., \& Darby, M. (1996). Star scientists and institutional transformation: Patterns of invention and innovation in the formation of the biotechnology industry. Proceedings of the National Academy of Sciences, 93(23), 12709-12716. 